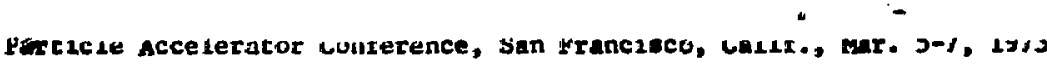

INJECTION INTK TRE ISA*

J. P. Blewett, R. Chammin, J. G. Cottinghaw, E. D. Courant, M. Month, E. Raka, and A. van Steenbergen Brookhaven Naticnal Laboratory

Upton, New York 11973

\title{
Abstract
}

Three modes of injection into the ISA storage accelerators are d1scussed. The three are: 1) Energy stacking in the ISA. 2) Acceleration of 12 bunches in the AGS followed by ingle bunch tranafer to the ISA. Application of a moving bucket technique then allows the transferred bunch to be brought closer to the bucket train clrculating in the ISA. 3) Acceleration on the flrut harmontc in the AGS. The single bunch is then transferred directly to the ISA Into a matchad bucket.

\section{Introduet tion}

In the Intersecting Storage Ring Accelerators ISABALE, 1 which have recentiy been proposed at brookhaven, protons are infected from the AGS at $30 \mathrm{GeV}$ and accelerated to $200 \mathrm{GeV}$. High luminosities are achieved by atoring beam currents of the ordar of $15 \mathrm{~A}$. Conufdering that the anticipated current in the AGS is 1.2 A and that the ISA c1rcumference is three times the ACS circumfarence, $\sim 36$ ACS pulses heve to be injectad to reach such an Intensity.

It 1s proposed that the ringe be f111ed by atecking in longltudinal phese opece. Thie does not only raduce aperture requlremente but eloo gived maxtrum luminosity if the beens in the storage ringe will be coasting. In that case, sosunins zero disparaton in the Interaction restion, the only luninoalty datermininis bee paresetar in addition to current is the tranowree enitetance, which will be minimim if the bean is atacked in longltudinal phase epace oniy.

Several longltudinal atacking whods thave been proposed involving aither azimuthnl or anergy utacking. Thay w111 be described in th10 paper and comparion batween them will be made. Consideration entering the cholce of aultable criteria, by which the nethode ohould be fudged, will be briefly mentioned.

\section{30-GeV Beam Parametera in the $\mathrm{ACS}$}

At the end of the accelerating cycle, 1.e., at flat top, in the AGS, the beam is expected to have the following longlitudinal characteristics:

Number of bunches:

Bunch half width:

Momentum half width:

Distance between bunche:

Total number of particles:

12

$9.8^{\circ}$ (y:f degrees)

$0.82^{\circ}$ (angular

$5.8 \times 10^{-4}$

$67 \mathrm{~m}$

$2 \times 10^{13}(1.2 \mathrm{~A})$

The rf parameters are:

Peak voltage per turn:

Frequency:

Harmonic number:
$360 \mathrm{kV}$

4.45 Nㅐ

12
* Work performed under the auspices of the W.S. Atomic Energy Commission.

\section{Azimuthal Stacking}

Three different azimuthal stacking methods have been proposed by which consecutive AGS bunches are stacked box-car type fashion around the ISA circumference. Both aingle and multiple bunch extraction in the AGS have bean considered.

a) Single bunch extraction (one bunch per, AGS pulve). Originally it was proposed by Blewett ${ }^{2}$ that the 12 bunches in the 108 be bunched into a single bunch by a sutooth osc111ator operated on the fundamentul frequency of the ACS. This wothd avold the use of extraordinnerily tant kickers needed to deposit the Individual bunches right mext to each other in the ISA. To ninteire the width of the single bunch it was suggested thet the benm be adtabatically debunched before rebunching into angle bunch takes place. Howrever, the adiabat le debunching would result in such a small momentur spread that unreasonably low coupling impedanees would be requited in the AGS to avold longitudinal Instabilitied.

An alternate way of forsing a ingle bunch in the ACS 10 to accelerate with an rf system operating on the fundarentel frequency of that archine. 3 A single bunch. whosa angular langth equalo the total angular length of the 12 Individual bunches can be obtalned if the re pesk voltage par turn is one-tweifth of that uned in the preaent 12th hareonle ayaten ( $30 \mathrm{kV}$ ) and the aynchronous phace of $150^{\circ}$, uad with that syotem to matntained. The momontun spresd of the elngle bunch equals the momantum apread of the 12 bunches under these condttions. The cholce of $30 \mathrm{kH}$ lungthen the acceleration cycle by a factor of 12. A thorter cycle cen be echleved without changling the base charactarlatice by solng to $50 \mathrm{kV}$ and a synchronous phese of $120^{\circ}$.

To be able to stack at nuny ACS pulses as posstble Into the ISh it wat alvo proposad to further compress the bean aclwuthally by the presently used 12th hacmonic rf ayotem. Taking full advantage of the voltage capacity of that oyoton the bunch length can be reduced by a factor of 3.7 by adiabat1e bunching.

The beam bunch can now be infected into the ISA, by use of rather conventional kickers, and captured in ISA rf buckets. Allowing for a kfcker rioe time of $\sim 40$ neec a maximum of 90 such bunches can be stacked in the ISA.

b) Muitiple bunch extraction (12 bunches per AGS pulse). Artmuthal stacking in the ISA can a1so be accomplished by athod suggented by Blewet and Cottingham. 4 The 12 bunches obtained with the existing 12th hamonte if syatem are extracted from the AGS at a time interval of 80 msec, sllowing the use of an alteady developed kiciker technique. The procedure can be described in the following way: A bunch from the AGS is transferred into the ISA. As soon as the kickers in the AGS and ISA recover, another bunch is extracted from the AGS and deposited in the ISA as close as possible ( 100 nwec) to the previlous bunch. By application of the moving bucket techniques suggested by Cottingham, 5 the second bunch in moved as close $a b$ is desired to the first bunch. The process is continued unt 11 all twelve bunches have been transferred. They will be held in a close sequence in the ISA by the ISA's if aystem which 
is to generate a train of waves of the same length as the sequence of stacked bunches. The procedure 18 repeated on subequent AGS pulses until both ISA rings are filled except for a short vacant portion after the lant bunch. This unfilled region corresponds to the rlue and fall time of the ISA klcker and occupies less than 3\% of the ISA c1rcumference. A maximum of 54 AGS pulses can be stacked in the ISA by this method asuuming no space between adjacent bunches.

\section{Energy Stacking}

Enargy stacking, the injection scheme presantly amployed in the CERN ISR, Involves moving an infuctad ban pulse by rf acceleration ecross a septum Into an area where the beam 10 parked. The septum protecto the -torad beam from the injection kick. This mathod can be adapted for the ISA in the following way6: Whth in ISh clrcumforence three tima the AGS clrcumference, three AGS pulses, consioting of 36 bunchus, are infectad Into the IBA by direct tranofer. The 36 bunches are captured in buckete of en If nyeten, operating at the 36th harmonic frequency at the ISA, and moved by acce1eration from the injection orbit into the parkins orbit. The ontire procedure can be repeated many times with the dilution in longltudinal phase opace depending on tha varlous parameters for the stacking procesa - for exaruple, the voltage turn-off t1we, the rate of acce1eration through the atack, and the dagres of penetret lon of the atack. In order to mintutize the asount of acceleration required to park the beam ateck at a vultable diatance away from the injection oxblt at the kicker position, the injection area has to be destinned (1) with a Large $x_{p}$ function $(\sim 4 \mathrm{~m})$, so that large movament of the beam can be made with a relatively anall momentum change, and (2) with a sall horlizonts Oufunction $(\sim 10 \mathrm{~m})$, so that tho amount of baam novement needed to koep the otack and Injocted bean separete 10 as emall as posotble. An infection Ingertion. fulf1liling thave conditions, hav been dosigned and incorporated Into the IBA lattice.

\section{Compar1eon of vethode}

Thera are many aspecte in which the diffarent in. jection methode can be compared. A fow of these w1Ll be wantionad here.

Quilltatively the following should be pointed out: While emergy otacking and astmuthal otacking by 12 bunch extraction do not require any modification in the AGS, ecceleration on the AGS fundamental frequency involves atraightforward but mafor engineerins effort in that machine. only energy tackling require: specially dealgned injection insertion in the ISA. Such an Insertion has been designed and does not seen to ceuse any problems regarding the lattice etructure.

The amount of hardware required in the different achemes is somewhat different but comparable. Al1 three methods require fast kickers. The aingle bunch extraction method calls for a new if aystem in the AGS, while the energy stacking scheme needs a spectal if system for acceleration into the parking orblt. The 12 binch extraction rothod requires pulae excited cavIt ies, but these would 130 be uned for acceleration to $200 \mathrm{GeV}$.

Finally the energy stacking method possesses a certain amount of flexibility in beam handling that the other two schemes do not have. Becnuse of the unilmited number of AGS pulses that can in principle be atacked by this method longitudinal atacking can be comblned with transiverse shaving to achieve high transverse beam densit Ies needed to Improve the luminosity.

Quantitatively the three wethode w111 be compared with respect to maximum number of stacked AGS pulses, stacking time, phase space dilution and momentum spread during stacking. Although it was assumed here that 36 AGS pulses have to be stacked into each ISA ring to achleve the design current of $15 \mathrm{~A}$, it $3 \mathrm{~s}$ worth mentioning that higher intensities can in principle be reached with all three ochemes. Alternatively, if the beam cur rent of $1.2 A$ cannot be obtained in the AGS, more than 36 AGS pulses are neceseary to achleve $15 \mathrm{~A}$ in the ISA. The following table shows the maximum number of AGS pulses that can be stacked in each ring by the different wathode:

\begin{tabular}{|c|c|c|}
\hline $\begin{array}{l}\text { Asfmuthel } \\
\text { One bunch } \\
\text { extract ion }\end{array}$ & $\begin{array}{l}\text { stacking } \\
12 \text { bunch } \\
\text { extraction }\end{array}$ & Energy Stacking \\
\hline
\end{tabular}

90

54

tunlimtted

The tim it takes to cherge the ringe w111 be made up by the acceleration $t$ tw in the AGS and the vtacking tim in the ISA. In the eximuthal stacking methods the tim to alnot conpletely taken up by acceleration in the AGs. In the energy atecking method additional time 1s taken up by otecking in the ISA. However, neither of the dancribad athode require aore than a fey minutes to stack each of the ISA ringe.

Ixpar lonce with the energy otacking method at the ISR tos shown that som longlfudinal phase epace dilution taked place. A dilution factor of 2 is quoted. It 10 not unroesonable to sosume that etmiler dilution uil1 take place with the eximuthal etacking methods. spactifcaliy, if the distance botwen adjacent bunches In the IEA is sal1, som phase apses dilution $v 111$ be Introduced by unnehrotion wotion in the nonilneer parts of the rf buckets.

The nomantum speacds obteined during stacking, acceleration and etoring wil vary posalbly be the nost Important condideretions in evaluat Ins the various injection schaess. This 1s becaune to enoure dapping of longltudinei Inntabilities the momentu epread has to, ba larger than a opecteled otniman valus. For a coantIns bean the following reletton has to hold botween the momantim spread, $\Delta p / p$, and the coupling ispedance $z_{k}$ (In otwes), corresposding to the kth hatmonic frequency:

$$
\left|\frac{z_{k}}{k}\right| \leq \frac{\pi}{I_{0}}\left(\frac{\Delta p}{P}\right)^{2}
$$

Here 2 10 the total enargy of the beas,

$$
\eta=\frac{1}{r_{t r}^{2}}-\frac{1}{r^{2}}
$$

and $I_{0}$ to the bean current (In ampares).

In order to get an eltimate of the required momentur upread in carb of a bunched baen, this formule can be uned 14 one repleces the avarage current $I_{0}$ w1th the penk current. Aseuning $\left|z_{k} / k\right| \sim 10 \Omega$ and on average current of $15 \mathrm{H}$, one cen calculate the nomentu spreed thet 1s required by each method to eupprese longltudinal

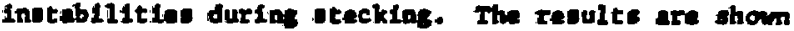
in Table I topether with ant leipated montin spreads based on 36 infected AGs pulese and a lonitudinal phace epece dilution fector of 2 .

Duripe scceleration and at $200 \mathrm{GeV}$ the momentum apread w111 be deternined by the if voltage and harmonic number of the ecceleration if ayaten. With the energy cteckine anthod, the boen wich 1s cossting in the parkles orblt, has to be robunched before ecceleration. There are no indiate constrainte in this cace on the cholee of the Irequancy of the accelerating rf eystan, 


\begin{tabular}{lll}
\hline$\Delta p / p$ & $\begin{array}{l}\text { Aximuthal stacking } \\
\text { One bunch }\end{array}$ & $\begin{array}{l}12 \text { bunch } \\
\text { extraction }\end{array}$ \\
\hline
\end{tabular}

Al hogluming of stuck Ing:

\begin{tabular}{ll}
$\begin{array}{l}\text { Reguired } \\
\text { Anticipated }\end{array}$ & $\left.\left(\mid \frac{z_{k}}{k}\right)=10 \Omega\right)$ \\
\hline
\end{tabular}

at end of stecking:

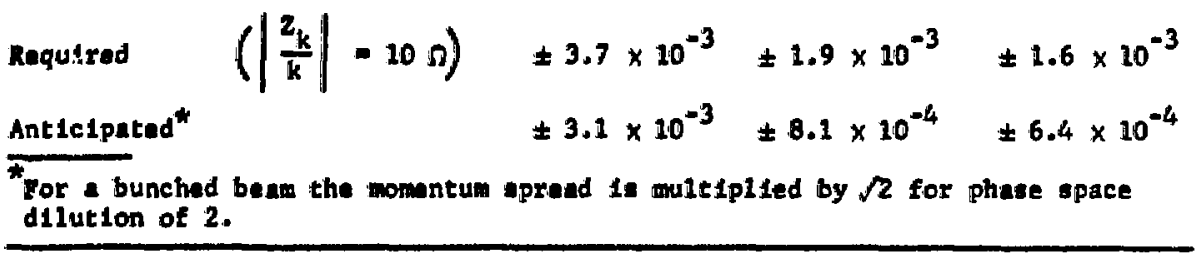

which io enother apect of flexiblitty in the energy atacking method. In the aximuthal stacking mothods the buckete of the accelerating if eystem huve to conform to the elready existing bean bunches. Turther otudy of lonstitudinal inutabilities of bunched baans is raquired to determine the proper characteriutics of the Is accelerating if aystan.

\section{6. sumary}

Three Iongitudinal phase opace atecklng mathode for Injecting AGS pulees Into the ISA have been dascribed. The three schamen, enploying elther astivithal or emrey stacking. all eaen to yield sat lotactory etecking time and efflctencles.

The difforent mathode result in unequel momentum

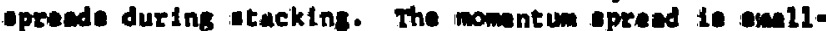
ast in the energy otacking echene for which the tolerable coupling impedance is of the order of 1 I for the fundementel frequancy $(k-1)$. Of course, thigher coupling Impedance can be tolerated by Inducins momentu epread dilution in the been.

Durins acceleration and at $200 \mathrm{ceV}$ the monentum epread of the bean w111 be deteralned iy the volteage and harmonic numer of the ISA accelerating if byetem. Further tudiee, explorins the condtions under which a bunched been become unstable, w111 determine the required cheracteriatice of this rf system. In turn, thi af eyotem w111 establiah definite requiremente for the injection schens.

\section{References}

1. 200-GeV Intersacting Storage Accelerators, ISABELLE, A Prelininary Design Study, Informal Report BiL 16716 (1972).

2. J. P. Blemet, Bri Accelerat or Dept. Informal Report ADD-169 (CRISP 71-6) (1971), See also 2. D. Courant, CRISP 71-5 (1971).

3. R. Chasman, Bin Accelerator Dept. Informal Report Cars? 72-94 (1972).

4. J. P. Dlowet and J. G. Cottingham, Brit Accelerstor Dapt. Infornal Roport MADD-195 (CRISP 72-93) (1972).

5. J. G. Cottinghan, Bat Acelerator Dept, Informul Report chisp $72-26(1972)$.

6. E. ToLll and A. M. Benslex, Br, Accelerator Dept. Informal Report CRIsP 72-74 (1972); M. Konth, C.ISP 72-89 (1972).

7. M. Month, Bh Accelerator Dept. Informal Report CRISP 72-88 (1972).

\section{Notice}

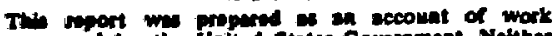
ponered by the Usiked Stetes Government. Nokther

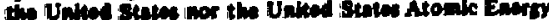

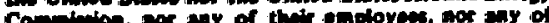

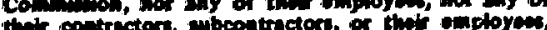

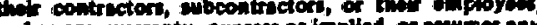

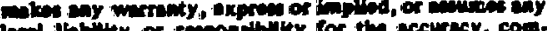

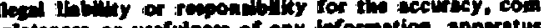

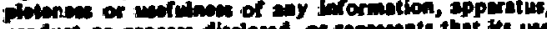

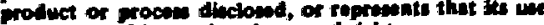
would sot infriape potvetely owiend rightw. 